\title{
A Swarm Optimization Based Method for Urban Growth Modelling
}

\author{
Sassan Mohammady \\ GIS Division, Department of Surveying and Geomatics Engineering, College of Engineering, University of \\ Tehran, Tehran, Iran \\ cross $^{\text {ref }}$ http://dx.doi.org/10.5755/j01.erem.69.3.6653
}

(Received in March, 2014; accepted in September, 2014)

\begin{abstract}
Land use activity is a major issue and challenge for town and country planners. Urban planners must be able to allocate urban land area to different applications with a special focus on the role and function of the city, its economy, and the ability to simulate the effect of user interaction with each other. Continuing migration of rural population to cities and population increases has caused many problems of today's cities including the expansion of urban areas, lack of infrastructure and urban services as well as environmental pollution. Local governments that implement urban growth boundaries need to estimate the amount of urban land required in the future given anticipated growth of housing, business, recreation and other urban activities. Urban growth is a complex process that encounters a number of sophisticated parameters that interact to produce the urban growth pattern. Urban growth modelling aims to understand the dynamic processes. Therefore, interpretability of models is becoming increasingly important. Different approaches have been applied in spatial modelling. In this study, Particle Swarm Optimization (PSO) has been used for modelling of urban growth in Qazvin city area (Iran) during 2005 to 2011. Landsat imageries, taken in 2005 and 2011 have been used in the study. Main parameters in this study are distance to residential area, distance to industrial area, slope, accessibility, land price and number of urban cell in a $3 * 3$ neighbourhood. Figure of Merit and Kappa statistics have been used for estimating accuracy of the proposed model.
\end{abstract}

Keywords: PSO, urban growth, GIS, urban planning

\section{Introduction}

Urban population worldwide has increased from $22.9 \%$ in 1985 to $47 \%$ in 2010 (Jiang et al, 2012). Studies predict that in $2025,56.6 \%$ of the entire world's population will live in the cities (UN, 2009). Therefore, the high density population and the public needs to absorb basic resources leads to uneven utilisation of resources (Bhatta, 2010). In some cases, the growth rate of urban areas was faster than population growth rate (Pijanowski et al, 2010). In recent years, rapid population growth and urbanisation has doubled importance of the land use. It could be stated that natural forces and human activities have been the most important factors in land use and land cover changes in local to global scale (Haub, 2007). However, the effect of human activities is more significant than natural forces. Negative effects of urban growth are the following: degradation of the environment, decreased quality of urban space and social degradation (Jenks, 2000).

Effort to better understand and analyse the relevant components of urban development can certainly help to solve urban problems (Rakodi, 2001). Understanding the urban characteristics and their interactions with other components of the environment, and use the knowledge/ ability to manage the environment for effective planning requires a better understanding of the environment and the dynamic pattern of different relations in space - time.

Understanding and recognition of the spatial and temporal dynamics of complex urban systems and assessing the impact of urban growth on the environment lies in the domain of modelling and simulation, which requires innovative approaches and 
techniques (Yong and Lo, 2003). Management and planning of urban spaces needs a careful monitoring of changes in patterns of land use. In this situation, urban growth models have been used by city planners and city managers. Urban modelling process consists of two phases. The first phase covers understanding of the dominant mechanisms for creating and making changes in the areas, while the second phase is prediction of the future (Foot, 1981).

Monitoring of the changes reveals the status of changes and pattern information for city managers and urban planners. A new field of soft computing in urban science is urban growth modelling. The soft computing can provide suitable and low cost solutions for environmental problems.

Today's urban construction and environmental changes are associated with various factors. Some urban policies can lead to undesirable consequences such as urbanised areas that have led to environmental damage. Based on the discussion of sustainable cities (Jenks et al., 2000), recognised factors can be a useful in evaluating urban policies. New patterns of urban sprawl development, decentralisation, urban policy outcomes could lead to new problems. Spatial distribution of urban settlements may result in increased threats to social, physical and natural hazards. Therefore, a large number of urban growth models have been developed to be used by urban planners. The main aim is to use these models in supporting smart decisions towards sustainable development in urban areas.

\section{Methods}

\subsection{Study area}

The study area in this paper is Qazvin region (Figure 1) that includes Qazvin city and 5 small cities around it. The study area is $450 \mathrm{~km}$ by $360 \mathrm{~km}$. Qazvin city is the capital of the province and has had the population 552928 in 1996 and this population reached 777975 in 2006. The main reason for population growth during 1996 - 2006 was increase of industrial and agricultural activities in this area. A number of new factories in this area made this city one of the most industrialised cities in Iran.
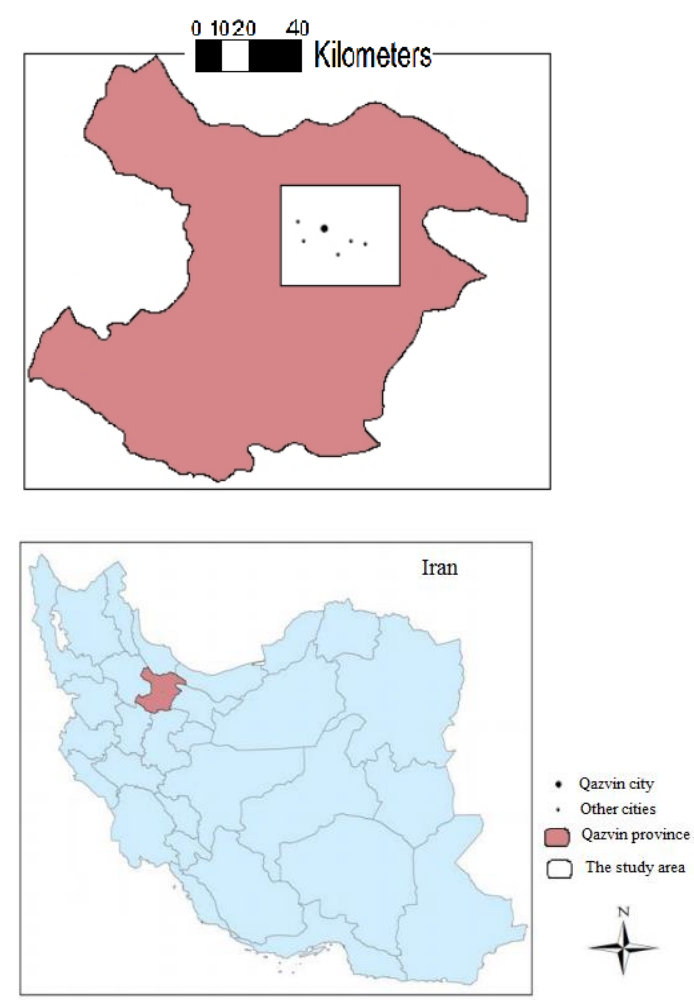

Fig. 1. The study area

Integration of algorithms and expert systems with reasoning and inference mechanisms enables development of knowledge-based models for describing and modelling of urban processes.

In this research, PSO approach has been used for modelling the physical development of Qazvin area from 2005 to 2011. Satellite imageries used in this study come from 2005 and 2011 Landsat ETM + sensor (Figure 2). ENVI 4.7 has been used in processing of satellite imageries. The land use map and accessibility network have been also used in shape file format in ArcGIS 9.3. In this study, attraction, economic and physical parameters have been considered. The dataset includes distance to residential area, distance to industrial area, accessibility, slope, land price and number of urban cell in a 3 by 3 neighbourhoods. All of input data is normalised according to Pijanowski et al, 2002 (Figure 3).

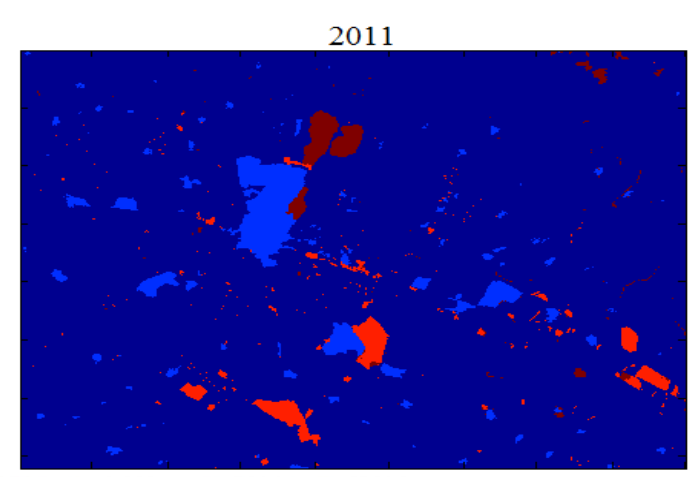

$6,000 \quad 24,000 \quad 32,000 \quad 40,000$

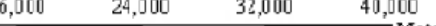

Fig. 2. The classified imageries 


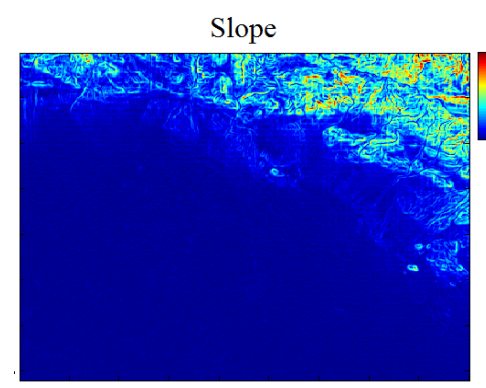

Accessibilty

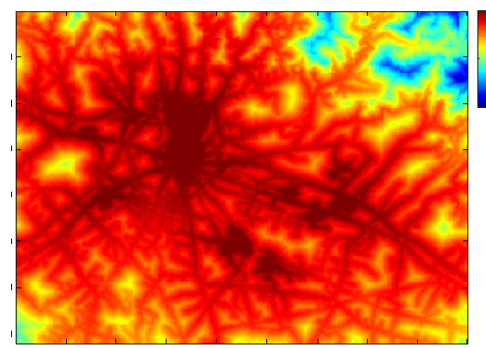

Distance to industrial area

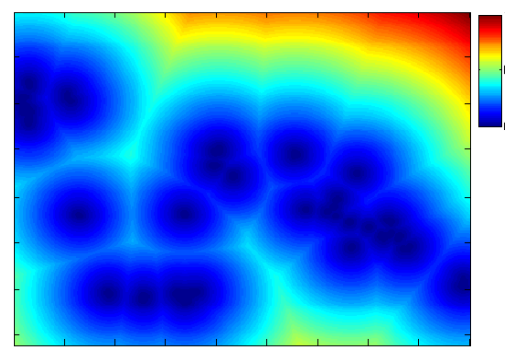

Datum: WGS 1984 Proj.: UTM Zone 39N
Number of urban cell in a $3 * 3$ neighborhood

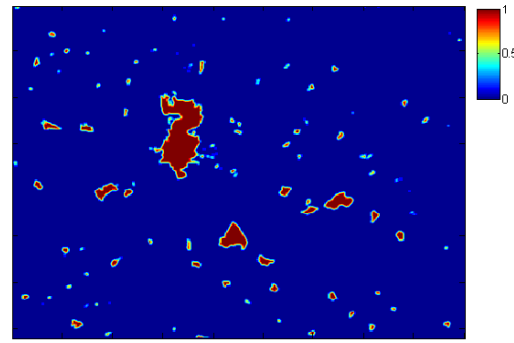

Distance to residential area

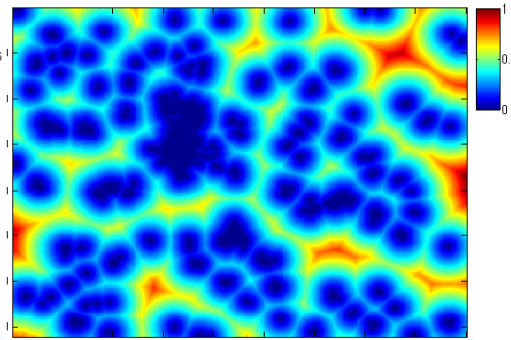

Land price

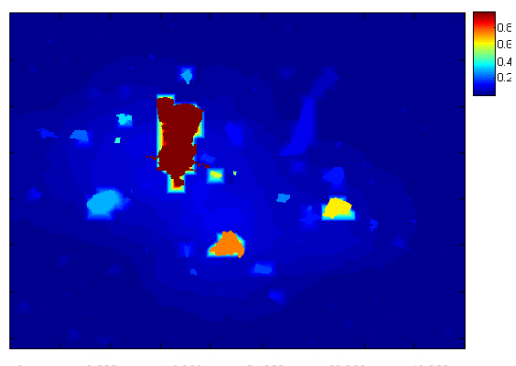

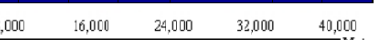

Fig. 3. The implemented dataset

\section{2. $P S O$}

Particle swarm optimization (PSO) method as an evolutionary computation technique has been developed by Kennedy and Eberhart in 1995 and is based on the social behaviour simulation (Kennedy \& Eberhart, 1995; Maurice, 2007). In this method, particles try to reach a better position (optimum fitness). In fact, the particles are moving towards promising regions of the search space by using their own experience during the search as well as experience of other particles (Parsopoulos and Vrahatis, 2008). Each particle stores the best position among all of the particles and the best position it has ever visited in the search space (Parsopoulos and Vrahatis, 2008). Equations 1and 2 present the update of the velocities and positions for each particle (Clerc and Kennedy 2002).

$$
\begin{aligned}
& v_{i j}^{t+1}=\chi\left(v_{i j}^{t}+c_{1} r_{1 j}^{t}\left[P_{b e s t, i}^{t}-x_{i j}^{t}\right]+c_{2} r_{2 j}^{t}\left[G_{b e s t}-x_{i j}^{t}\right]\right) \\
& x_{i j}^{t+1}=x_{i j}^{t}+v_{i j}^{t+1}
\end{aligned}
$$

Where: $\quad i=1,2, \ldots, N$;

$j=1,2,3, \ldots, n$;

$\mathrm{c}_{1}, \mathrm{c}_{2}$ - positive constants called cognitive and social parameters;

$\mathrm{r}_{1}, \mathrm{r}_{2}$ - independent random parameters between 0 to 1 ;

\begin{abstract}
$\chi$ - constriction factor;
$\mathrm{G}_{\text {best }}$ - the best position in all of iterations between all of particles;

$\mathrm{P}_{\text {best }}$ - the best position for each particle.
\end{abstract}

This method has been used in urban growth modelling by Pinto et al, 2011; Feng et al, 2011; Rabbani et al, 2012. According to $\mathrm{Wu}, 2002$, the probability for a cell in the position of $(i, j)$ to convert from non-urban to urban state can be computed from the following equation (White \& Engelen, 1993; Wu, 2002):

$P_{i j}^{t}=\left(P_{l}\right)_{i j} \times\left(P_{\Omega}\right)_{i j} \times \operatorname{Con}(.) \times P_{r}$

Where $\left(\mathrm{P}_{1}\right)_{\mathrm{ij}}$ is a logistic regression function which is used to obtain the value of each cell to convert from non-urban to urban. Distance to residential area, distance to industrial area, accessibility and land price are in the logistic regression as the inputs (Equation 4). During the training process, the parameters coefficient is determined.

$$
\left(P_{l}\right)_{i j}=\frac{1}{1+\exp \left[-\left(a_{0}+\sum_{k=1}^{m} a_{k} \cdot d_{k}\right)\right]}
$$


Where: $\quad d_{k}$ - effective parameters (Distance to residential area, distance to industrial area, accessibility and land price);

$\mathrm{a}_{0}$ - constant parameter;

$a_{k}$ - coefficients of each of the independent parameters that must be calculated.

$\left(P_{\Omega}\right)_{i j}$ is the number of urban cell in the cell's neighbourhood (Equation 5). In this research, Moore neighbourhood is used as the neighbourhood definition.

$$
\left(P_{\Omega}\right)_{i j}=\frac{\operatorname{Count}\left(S_{i j}^{t}==U r b a n\right)}{n^{2}}
$$

Con (.) relates to the natural limitations and constraints such as slope and elevation or proximity of specific areas in the research area. It also depends on areas that are prohibited for future development, e.g. military areas, protected areas like national parks, etc. Physical conditions like slope and elevation are the most important ones. The urban development in this area is expensive and time consuming (development of urban infrastructure, transportation and construction of facilities). Thus, existence of this factor is unavoidable. In this research, we considered slope factor as the constraint. The 20 degree slope is the threshold value. Thus, cell with slope value higher than the threshold value is 0 and lower value is considered $1 . \mathrm{P}_{\mathrm{r}}$ factor is used to model the effect of random errors. According to $\mathrm{Wu}, 2002$, fitness function in this study is proposed in equation 6 .

$$
F(a)=\sum_{i=1}^{N} \sum_{j=1}^{M}\left(P_{i j}(a)-f_{i j}^{0}\right)^{2}
$$

Our aim is to minimise the fitness function.

\subsection{Accuracy assessment}

Kappa. Kappa coefficient, as a statistical method is used for evaluating model performance in modelling urban development and similarity between two maps (imageries). This method is a well-known method in measuring similarity between two maps and have been used by (Monserud and Leemans, 1992, Hagen, 2003, Pijanowski et al, 2005, 2009, Foroutan and Delavar, 2012, Mohammady, 2013, Bhagyanzgar et al, 2012, Fonji and Taff, 2014, Yuan et al, 2005, Erener and Düzgün, 2009, Satiprasad, 2013, Reis, 2008, Torahi and Rai, 2011, Pontius et al, 2001, Fuglsang et al, 2012, Samardzic-Petrovic, 2013). This index can help in measuring the similarity of two maps of the spatial distribution (Congalton and Green, 2009). This procedure is more appropriate because it uses all elements of comparison matrix for assessing the compatibility of simulation and reality maps. Table 1 illustrates the general shape of the probability. Table 1 is used to calculate kappa from the comparison matrix and its elements are obtained. Kappa coefficient is calculated using equation (9) (Pijanowski et al., 2005).

\begin{tabular}{|c|c|c|c|c|c|c|}
\hline \multicolumn{6}{|c|}{ Model } & \multirow{2}{*}{ Total } \\
\hline \multirow{5}{*}{ Real } & Class & 1 & 2 & $\ldots$ & $\mathrm{C}$ & \\
\hline & 1 & $\mathrm{P}_{11}$ & $\mathrm{P}_{12}$ & $\ldots$ & $\mathrm{P}_{1 \mathrm{C}}$ & $\mathrm{P}_{1 \mathrm{~T}}$ \\
\hline & 2 & $\mathrm{P}_{21}$ & $\mathrm{P}_{22}$ & $\ldots$ & $\mathrm{P}_{2 \mathrm{C}}$ & $\mathrm{P}_{2 \mathrm{~T}}$ \\
\hline & $\ldots$ & $\ldots$ & .. & $\ldots$ & $\ldots$ & $\ldots$ \\
\hline & $\mathrm{C}$ & $\mathrm{P}_{\mathrm{C} 1}$ & $\mathrm{P}_{\mathrm{C} 2}$ & $\ldots$ & $\mathrm{P}_{\mathrm{CC}}$ & $\mathrm{P}_{\mathrm{CT}}$ \\
\hline \multicolumn{2}{|c|}{ Total } & $\mathrm{P}_{\mathrm{T} 1}$ & $\mathrm{P}_{\mathrm{T} 2}$ & & $\mathrm{P}_{\mathrm{TC}}$ & \\
\hline
\end{tabular}

Table 1. Comparison matrix

$P(A)=\sum_{i=1}^{C} P_{i i}$

$P(E)=\sum_{i=1}^{C} P_{i T} \cdot P_{T i}$

$K S=\frac{P(A)-P(E)}{1-P(E)}$

It is generally considered that Kappa values for map agreement are the following: $>0.8$ is excellent; $0.6-0.8$ is very good; $0.4-0.6$ is good; $0.2-0.4$ is poor and $<0.2$ is very poor (Pijanowski et al., 2005, Foroutan and Delavar, 2012).

Figure of Merit. Figure of Merit (Equation 10) is a method to evaluate resemblance between actual and simulated map. This method has been developed in 2008 (Pontius et al, 2008). When a simulated map has a high goodness of fit to actual map, Figure of Merit will be high and vice versa. This factor ranges between 0 and 1 . The value 1 indicates that all of the target class simulated correctly and 0 indicates that all of the target class cells have been simulated wrongly.

Figure of Merit $=\frac{b}{a+b+c+d}$

Where: $\quad a$ - error due to observed change predicted as a persistence;

$b$ - correct due to observed change predicted as change;

$c$ - error due to observed change predicted as wrong gaining category;

$d$ - error due to observed persistence predicted as change.

Percent Correct Match (PCM). Percent Correct Match (PCM) is another evaluation method which is used for measuring similarity between two maps. Percent Correct Match is calculated using the Confusion matrix (Table 2) (Pontius and Schneider, 2001) (Equation 11). This factor ranges from 0 to 1. The value 1 means perfect agreement between two maps (simulated map and the real one). The 0.5 value means random disturbance of land use classes on the map. The 0 value mean perfect disagreement between two maps. Thus, the value closer to 1 means better similarity between two maps. 
Table 2. $\quad$ Confusion matrix

\begin{tabular}{|c|c|c|c||}
\hline \multirow{2}{*}{ Model } & \multicolumn{3}{|l|}{ Real } \\
\cline { 2 - 4 } & Urban & Non-urban & Total \\
\hline Urban & $\mathrm{A}$ & $\mathrm{B}$ & $\mathrm{A}+\mathrm{B}$ \\
\hline Non-urban & $\mathrm{C}$ & $\mathrm{D}$ & $\mathrm{C}+\mathrm{D}$ \\
\hline Total & $\mathrm{A}+\mathrm{C}$ & $\mathrm{B}+\mathrm{D}$ & $\mathrm{A}+\mathrm{B}+\mathrm{C}+\mathrm{D}$ \\
\hline
\end{tabular}

$P C M=\frac{A+D}{A+B+C+D}$

\section{Results and discussion}

In this study, the number of swarms proposed is 2500. Number of swarms and iteration are the parameters which have effect on PSO performance (Carlisle and Dozier, 2001). Large number of swarms makes the program time-consuming. It also requires more data on spaces. On the other hand, little number of swarms may lead to finding local optimum instead of global optimum and it is considered to be an issue. Thus, finding the proper number of swarms is an important task in working with PSO. In this study, 2500 swarms searched the space in 500 epochs. Figure 4 shows the training performance of PSO. The Gbest cost starts around 2643.8 and reached 54.9424 in 500 epochs. The logistic regression parameters are shown in Table 3. According to Table 3, accessibility has had the biggest coefficient and this parameter could be considered as the most important factor in development of the region.

Table 3. The logistic regression parameter

\begin{tabular}{||l|c||}
\hline \multicolumn{1}{|c|}{ Parameters } & Coefficient \\
\hline Accessibility & -12.7082 \\
\hline Land price & 0.3482 \\
\hline Distance to industrial area & 0.5453 \\
\hline Distance to residential area & -5.9294 \\
\hline Constant & 12.3199 \\
\hline
\end{tabular}

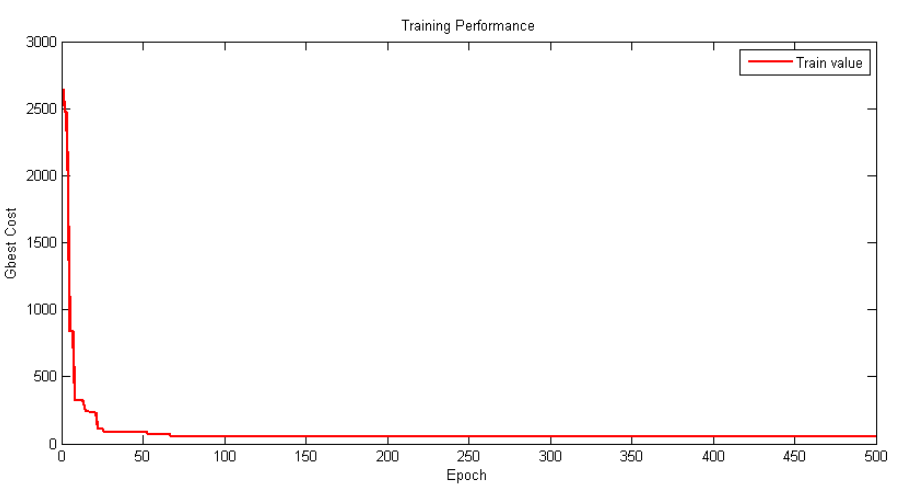

Fig. 4. The PSO training performance

The result of modelling using the PSO structure is presented in the Figure 5. The Kappa statistics (Table 4), Figure of Merit and calculated Percent Correct Match are 0.6614, 0.5386 and 0.9752 respectively. According to Pijanowski et al, 2005 and Sousa et al, 2002, the obtained Kappa statistics from the simulation of 2011 map is considered as very good model.

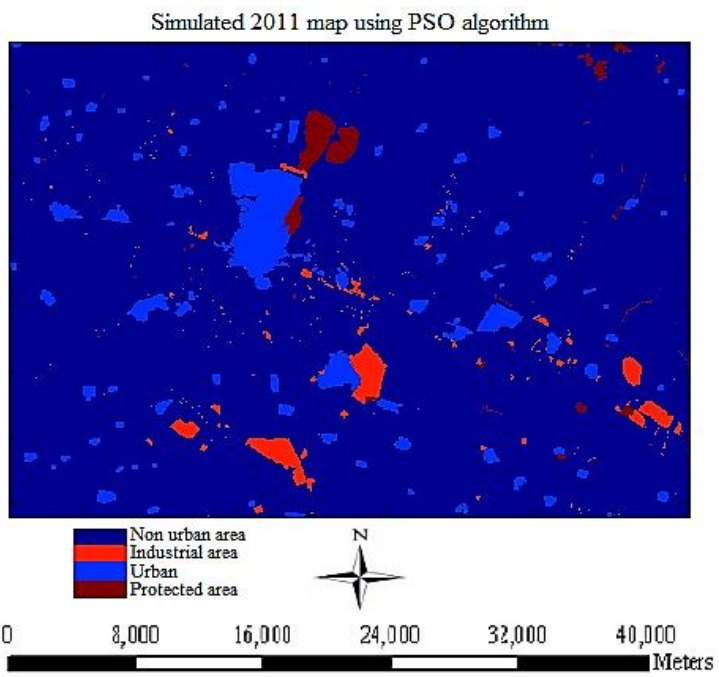

Fig. 5. The simulated 2011 map using PSO algorithm 
Table 4. The obtained comparison matrix

\begin{tabular}{||l|l|c|c|c||}
\hline \multicolumn{4}{|c|}{ Model } & \multirow{2}{*}{ Total } \\
\hline \multirow{3}{*}{ Real } & Class & Urban & Non-urban & \\
\cline { 2 - 5 } & Urban & 0.0257 & 0.0123 & 0.0380 \\
\cline { 2 - 5 } & Non-urban & 0.0125 & 0.9495 & 0.962 \\
\cline { 2 - 5 } & Total & 0.0380 & 0.9618 & 1.000 \\
\hline
\end{tabular}

Additionally, the obtained confusion matrix is presented in the Table 5 .

Table 5. The obtained comparison matrix

\begin{tabular}{||c|c|c|c|}
\hline \multirow{2}{*}{ Model } & \multicolumn{3}{|l|}{ Real } \\
\cline { 2 - 4 } & Urban & Non-urban & Total \\
\hline Urban & 4162 & 1994 & 6156 \\
\hline Non-urban & $\mathbf{2 0 2 7}$ & $\mathbf{1 5 3 8 1 7}$ & $\mathbf{1 5 5 8 4 4}$ \\
\hline Total & 6189 & 155811 & 162000 \\
\hline PCM $=0.9752$
\end{tabular}

\section{Conclusions}

Integration of swarm based algorithms, Geospatial Information System (GIS) tools and remote sensing data can be considered as a powerful scientific method in monitoring, analysing and modelling urban growth. In this study, PSO algorithm is used for modelling of the development of the Qazvin city during 2005 - 2011.

A big swarm number causes larger parts of the search space to be searched and it may reduce the number of iterations needed to obtain a good optimisation result. Needless to say, a big swarm size is time-consuming.

The simulated 2011 map using PSO algorithm has had an acceptable agreement to the real 2011 map. The Kappa statistics, PCM and Figure of Merit obtained from this simulation are equal to 0.6614 , 0.9752 and 0.5386 respectively. According to recent researches (Pijanowski et al, 2005, Sousa et al, 2002), the kappa statistics in this research could be considered as very good. According to Pontius et al, 2008, the Figure of Merit obtained from this research is acceptable.

According to Table 3, accessibility has obtained the highest value in the logistic regression coefficients and thus, accessibility is the most important factor in development of Qazvin region during 2005 - 2011 (Table 2). On the other hand, land price due to the least value in the logistic regression coefficients has the least effect on developing of Qazvin region.

According to Figure 2, a large volume of development in 2005 - 2011 has happened in the industrial area. This city has attracted a large population during recent years. In the context of huge population growth and increasing rate of agricultural land transformation to the urban area, the city planners and urban manager should prepare policies for future development of the city, especially in agricultural areas.

Two satellite imageries have been used to analyse urban expansion for Qazvin city. The greater number of satellite imageries and imageries with smaller ground pixel size like Quickbird and Ikonos satellite imageries data definitely increase accuracy and reliability of research results. However, it should be mentioned that these data are not free and more important than that, for a developing country like Iran, which historical urban data and land use map is not stored properly or not even existed, the research using free and reliable satellite imageries data is a practical scientific method for analysing urban growth.

In this study, the modelling and simulation procedure is done using economic, physical and attraction data. The physical data (slope), economic data (land price) and attraction data include distance to residential area, distance to industrial area, accessibility and number of urban cell in a 3 by 3 neighbourhoods. It should be mentioned that greater number of input parameters can be examined by the model. Needless to say, the model has no limitation concerning the number and type of input data. In spite of so many other models like SLEUTH, CLUE-S which unable to cover social data, this model covers all sort of data. The dataset can be improved using more input data. Attraction data like distance to green space and distance to region centers, social data like population density, population income and physical data like elevation and distance to fault, can also be examined in the model. However, the greater number of input data needs more time for training the model. In other words, the greater number of input parameters make the computation very time consuming. Thus, finding the proper number of input data is an important task.

This method is a reliable tool for urban planners and city managers to identify the future urban expansion trends and to examine their policies. Urban planners can predict urban expansion for the future periods and analyse the population growth rate to prevent occurring urban sprawl. It could also be used for area allocation for different facilities in the urban areas in the future plans.

\section{References}

Bhagyanagar R., Kawal B M, Dwarakish G S and Surathkal S., Land use/land cover change and urban expansion during 1983-2008 in the coastal area of Dakshina Kannada district, South India, J. Appl. Remote Sens. 6(1), $063576 \quad$ (Sep 21, 2012). http://dx.doi.org/10.1117/1.JRS.6.063576.

Bhatta B., Analysis of Urban Growth and Sprawl from Remote Sensing Data, 2010, Berlin, Heidelberg: SpringerVerlag. http://dx.doi.org/10.1007/978-3-642-05299-6

Carlisle A and Dozier G., An Off-The-Shelf PSO, in Workshop Particle Swarm Optimization, Indianapolis, 2001.

Clerc M. and Kennedy J. (2002), The particle swarmexplosion, stability, and convergence in multidimensional complex space a multidimensional complex space. IEEE 
Trans Evol. Comput., 6(1), p. 58-73. http://dx.doi.org/10.1109/4235.985692

Congalton R.G. and K. Green, "Assessing the Accuracy of Remotely Sensed Data: Principles and Practices". 2nd Edition. 2009, CRC/Taylor \& Francis, Boca Raton, 183.

Erener A. and Düzgün H. S. (2009), A methodology for land use change detection of high resolution pan images based on texture analysis, Italian Journal of Remote $\begin{array}{llll}\text { Sensing, } & 41 & \text { (2): } & 47-59 .\end{array}$ http://dx.doi.org/10.5721/ItJRS20094124

Feng Y., Liu Y., Tong X., Liu M., and Deng S. (2011), Modeling dynamic urban growth using cellular automata and particle swarm optimization rules, Landscape and Urban Planning, 102, p. 188-196. http://dx.doi.org/10.1016/j.landurbplan.2011.04.004

Fonji S. F. and Taff G. N. (2014), Using satellite data to monitor land-use land-cover change in North-eastern Latvia, SpringerPlus, 3:61 .http://dx.doi.org/10.1186/21931801-3-61

Foot D., Operational Urban Models: An Introduction, 1981, Methuen London.

Foroutan E. and Delavar M.R., Urban growth modeling using fuzzy logic, ASPRS 2012 Annual Conference Sacramento, California, March 19-23, 2012.

Fuglsang M., Münier B. and Hansen H. S., Modelling land use changes according to transportation scenarios using raster based GIS, indicators. International Environmental Modelling and Software Society (iEMSs) 2012 International Congress on Environmental Modelling and Software Managing Resources of a Limited Planet, Sixth Biennial Meeting, Leipzig, Germany.

Hagen A. (2003). Multi-method assessment of map similarity. International Journal of Geographical Information $\quad$ Science, 17(3), 235-249. http://dx.doi.org/10.1080/13658810210157822

$\begin{aligned} & \text { Haub C., World population data } \\ & \text { Reference }\end{aligned} \begin{aligned} & \text { sheet. 2007, } \\ & \text { Population } \\ & \text { http://www.prb.org/pdf07/07WPDS_Eng.pdf. }\end{aligned}$

Jenks, M. And E. Burton, Achieving Sustainable Urban Form, 2000, Spon Press.

Jiang L., Deng X., and Seto K.C. (2012), Multi-level modeling of urban expansion and cultivated land conversion for urban hotspot counties in China, Landscape and Urban Planning, 108, p. 131-139. http://dx.doi.org/10.1016/j.landurbplan.2012.08.008

Kennedy J., and Eberhart R.C., Particle swarm optimization. In IEEE international conference on neural networks, 1995, p. 1942-1948.

Maurice C., Particle swarm optimization. 2007, London: ISTE Ltd.

Monserud R.A. and Leemans R. (1992). Comparing global vegetation maps with the Kappa statistic. Ecological Modelling, 62(4), 275-293. http://dx.doi.org/10.1016/03043800(92)90003-W
Mohammady S, A Logistic Regression Method for Urban growth modeling Case Study: Sanandaj City in IRAN, $7^{\text {th }}$ SASTech, Bandar-Abbas, Iran, March, 2013.

Pinto N. Antunes, and Cladera J., Calibration of a cellular automata model with the particle swarm algorithm, GeoComputation 2011, Session 1B: Genetic Algorithms \& Cellular Automata Modelling.

Parsopoulos and Vrahatis, IGI Global, MultiObjective Particles Swarm Optimization Approaches, 2008, p. 20-4.2.

Pijanowski B. L. Iverson C. Drew, H. Bulley, J. Rhemtulla, M. Wimberly, A. Bartsch And J. Peng (2010), Addressing the interplay of poverty and the ecology of landscapes: A grand landscape ecologists? Landscape Ecology, 25, p. 5-16. http://dx.doi.org/10.1007/s10980-0099415-z

Pijanowski B.C., Pithadia S., Shellito B.A. and Alexandridis K. (2005). Calibrating A neural networkbased urban change model for two metropolitan areas of the Upper Midwest of the United States. International Journal of Geographical Information Science, 19, p. 197-215. http://dx.doi.org/10.1080/13658810410001713416

Pijanowski B.C., Tayyebi A., Delavar M.R. and Yazdanpanah M. J. (2009). Urban expansion simulation using geographic information systems and artificial neural networks. International Journal of Environmental Research, 3(4), 493-502.

Pontius Jr. R.G., Boersma W., Castella J.C., Clarke K., De Nijs T., Dietzel C., Zengqiang D., Fotsing E., Goldstein N., Kok K., Koomen E., Lippitt C.D., Mcconnell W., Pijanowski B., Pithadia S., Sood A.M., Sweeney S., Trung T.N., Veldkamp A.T., and Verburg P.H. (2008), Comparing the input, output, and validation maps for several models of land change. Annals of Regional Science, 42, p. 11 - 47. http://dx.doi.org/10.1007/s00168-007-0138-2

Pontius R. G., Cornell J. D., And Hall C. A. S., Modeling the spatial pattern of land-use change with GEOMOD2: application and validation for Costa Rica, Agriculture, Ecosystems and Environment 85, 2001, 191203. http://dx.doi.org/10.1016/S0167-8809(01)00183-9

Pontius Jr. R.G., Schneider L.C. (2001), Land-cover change model validation by an ROC method for the Ipswich watershed, Massachusetts, USA, Agriculture, Ecosystems \&Environment, 85(1-3), 239-248. http://dx.doi.org/10.1016/S0167-8809(01)00187-6

Rakodi C. (2001). Forget planning, put politics first? Priorities for urban management in developing countries, International Journal of Applied Earth Observation and Geoinformation, 3(3), p. 209-223. http://dx.doi.org/10.1016/S0303-2434(01)85029-7

Rabbani A.H., Aghababaee H. and Rajabi M.A. (2012). Modeling Dynamic Urban Using Hybrid Cellular Automata and Particle Swarm Optimization, Journal of Applied Remote Sensing, 6 (1), id:063582 10 p.

Reis S, Analyzing Land Use/Land Cover Changes Using Remote Sensing and GIS in Rize, North-East Turkey, Sensors 2008, 8, 6188-6202; DOI: 10.3390/s8106188. 
Samardžić-Petrović M., Bajat B., and Kovačević M. Assessing similarities between planned and observed land use maps: the belgrade's municipalities case study, GIS Ostrava 2013 - Geoinformatics for City Transformation January $21-23,2013$, Ostrava.

Satiprasad S., Monitoring urban Land use land cover change by Multi-Temporal remote sensing information in Howrah city, India, International Research Journal of Earth Sciences, 1(5), 1-6, October (2013)

Sousa S., Caeiro S. and Painho M., Assessment of map similarity of categorical maps using Kappa Statistics: The Case of Sado Estuary. Paper presented at the ESIG 2002, Tagus Park, Oeiras.

Torahi A. A., and Rai S. C., Land Cover Classification and Forest Change Analysis, Using Satellite Imagery - A Case Study in Dehdez Area of Zagros Mountain in Iran, Journal of Geographic Information System, 2011, 2 3, $1-11$. http://dx.doi.org/10.4236/jgis.2011.31001

UNITED NATION, Urban And Rural Areas 2009, Department of Economic and Social Affairs, Population Division, 2009, www.unpopulation.org.

White R. and Engelen G., High-resolution integrated modelling of the spatial dynamics of urban and regional systems. Computers, Environment and Urban Systems,
2000, 24, p. 383-400. http://dx.doi.org/10.1016/S01989715(00)00012-0

Wu F. (2002), Calibration of stochastic cellular automata: The application to rural-urban land conversions. International Journal of Geographical Information Science, 16(8), p. 795-818. http://dx.doi.org/10.1080/13658810210157769

Yang X. and Lo C.P. (2003), Modeling urban growth and landscape changes in the International Journal of Geographical Information Science, Atlanta metropolitan area, 17 , p. $463-488$.

Yuan E, Sawaya K.E., Loeffelholz B.C. and Bauer M.E. (2005). Land cover classification and change analysis of the Twin Cities (Minnesota) Metropolitan Area by multitemporal Landsat remote sensing, Remote Sensing of $\begin{array}{llllll}\text { Environment } & 98, & 317 & - & 328 .\end{array}$ http://dx.doi.org/10.1016/j.rse.2005.08.006

Sassan Mohammady - GIS division, Department of Surveying and Geomatics Engineering, College of Engineering, University of Tehran, Tehran, Iran. Main research area: Urban growth modelling.

Tel.: $\quad+989181731932$

E-mail: Sassanmohammady@yahoo.com 


\section{Miesto plètros modeliavimas naudojantis dalelių spiečiaus optimizavimo metodą}

\section{Sassan Mohammady}

GIS skyrius, Tyrimu ir geomatikos inžinerijos fakultetas, Inžinerijos koledžas, Teherano universitetas, Teheranas, Iranas

(gauta 2014 m. kovo mèn., priimtas spaudai 2014 m. rugsëjo mèn.)

Žemès sklypų išnaudojimas yra pagrindinè problema ir iššūkis, su kuriuo susiduria kiekvienas miestų ir kaimų teritorijų planuotojas. Miestų planų rengejjai turi gebėti urbanistines teritorijas paskirstyti naudoti pagal paskirti, ypatingą dèmesi skirti miesto savitoms savybèms, jo funkcionalumui, atkreipti dèmesị i miesto ekonominį lygi, numatyti ir atkurti sąveikos ryšius tarp vartotojų. Besitęsianti migracija i miestus bei populiacijos augimas sukèlè daug problemu šiandieniniams miestams, iskaitant miesto teritoriju plètimassi, infrastruktūros bei miesto paslaugų prieinamumo trūkumą ir aplinkosauginę taršą. Vietos valdžios institucijos, nustatančios miestų augimo ribas, turi ịvertinti miesto plètrai reikalingą žemès teritorijos dydį, numatyti naujų būstų, verslo plètros, poilsio zonų ir kitų miestui būdingų bei reikalingų teritorijų poreikio augimą, neperžiangiant nustatytų naujų miesto ribų. Miesto plètros modeliavimo tikslas yra suprasti dinamikos procesą, dèl to pačio modelio interpretacija tampa esminè.

Erdviniam modeliavimui buvo pritaikyti keli skirtingi būdai. Šiame tyrime Qazvin miesto nuo 2005 iki 2011 metų plètros modeliavimui buvo naudojamas dalelių spiečiaus optimizavimo (PSO) metodas. PSO yra gerai žinomas algoritmas, sudarytas remiantis dalelių spiečiaus optimizavimu, taikomu daugelyje tyrimų, ieškant optimalios parametro reikšmès. Studiju sritis apima Irano miesta Qazvin, kurio gyventoju skaičius per keletą pastarujų dešimtmečių itin sparčiai augo. Tyrimui naudoti satelitiniai vaizdai buvo užfiksuoti 20052011 metų laikotarpiu. Miestų augimas yra sudètingas struktūrinis procesas, kurio metu tarpusavyje sąveikauja gausybė sudètingų parametrų, kurdami augančio miesto modelį. Šiame tyrime pagrindiniai parametrai yra atstumas iki gyvenamosios teritorijos, atstumas iki pramoninių teritorijų, šlaitas, prieinamumas, žemės kaina bei skaičius $3 * 3$ miestiškojo plotų kaimynystėje. Kad analizè būtų kuo tikslesne் tyrimui ịvertinti buvo naudojamas kokybès rodiklis, procentalus tikslumo apskaičiavimas ir Kappa statistika, nustatyti jų dydžiai buvo atitinkamai $0.5386,0.9752$ ir 0.6614 . 